\title{
Management of Secondary Hyperparathyroidism: The Importance and the Challenge of Controlling Parathyroid Hormone Levels without Elevating Calcium, Phosphorus, and Calcium-Phosphorus Product
}

\author{
Sharon M. Moe a Tilman B. Drüeke ${ }^{b}$ \\ a Department of Medicine, Division of Nephrology, Indiana University School of Medicine and \\ Roudebush Veterans Affairs Medical Center, Indianapolis, Ind., USA; b Inserm Unité 507, Division of Nephrology, \\ Hôpital Necker, Paris, France
}

\section{Key Words}

Secondary hyperparathyroidism $\cdot$ Parathyroid hormone $\cdot$ Chronic kidney disease $\cdot$ End-stage renal disease $\cdot$ Hypercalcemia $\cdot$ Calcium-phosphorus product . Bone disease $\cdot$ Cardiovascular disease

\begin{abstract}
Secondary hyperparathyroidism (HPT) is a common complication of chronic kidney disease (CKD) that can lead to clinically significant bone disease. Additional consequences of secondary HPT, such as soft-tissue and vascular calcification, cardiovascular disease, and calcific uremic arteriolopathy, may contribute to the increased risk of cardiovascular morbidity and mortality among CKD patients. Secondary HPT arises from disturbances in calcium, phosphorus, vitamin D and parathyroid hormone metabolism, which develop early in the course of CKD and become more prominent as kidney function declines. The standard therapies currently recommended to correct mineral metabolism and bone disease in these patients include calcium supplementation, dietary phosphorus restriction, phosphate-binding agents, and treatment with vitamin D sterols. However, such medications often have significant effects on the
\end{abstract}

\section{KARGER}

Fax +41613061234 E-Mail karger@karger.ch www. karger.com
(C) 2003 S. Karger AG, Basel

0250-8095/03/0236-0369\$19.50/0

Accessible online at: www. karger.com/ajn serum levels of calcium and phosphorus, which result in exacerbation of the disease and significant extraskeletal morbidity and mortality. Thus, there is a need to identify more effective treatment approaches. This review discusses the pathophysiology of secondary HPT, the challenges faced in the management of this disorder, and the impact of current treatment options on patients' risks of morbidity and mortality. In addition, the development of new, more physiologically relevant therapies, which may lead to successful management of secondary HPT, is reviewed.

Copyright $@ 2003$ S. Karger AG, Basel

\section{Introduction}

Secondary hyperparathyroidism (HPT) is a common complication of chronic kidney disease (CKD), and is characterized by elevated levels of serum parathyroid hormone (PTH) and abnormalities in bone and mineral metabolism [1]. This serious disorder arises from disturbances in the regulation of the intracellular and extracellular levels of PTH, calcium, phosphorus, and vitamin D (calcitriol), which become more severe as kidney function declines. The interaction between these factors is com- 
plex, and effective control of secondary HPT can create a significant challenge.

Abnormalities associated with secondary HPT begin in the early stages of CKD [2]. Abnormal PTH, calcium, and phosphorus concentrations lead to many pathologic features of the disease, including symptomatic bone disease, extraskeletal calcifications, and an increased risk of mortality. Recognition of these risks has led to the proposal of new target levels of serum phosphorus (3.5-5.5 mg/ $\mathrm{dl})$, calcium-phosphorus product $\left(\mathrm{Ca} \times \mathrm{P} ;<55 \mathrm{mg}^{2} / \mathrm{dl}^{2}\right)$, serum PTH (150-300 pg/ml), and serum calcium (8.4$9.6 \mathrm{mg} / \mathrm{dl}$ ), which are soon to be published in the National Kidney Foundation's Kidney Disease Outcomes Quality Initiative (NKF-K/DOQI) Bone Metabolism and Disease Guidelines [3].

Standard therapy for secondary HPT includes calcium supplementation, dietary phosphorus restriction, phosphate-binding agents, and treatment with calcitriol and other active vitamin D sterols. These therapies have major direct or indirect effects on serum levels of calcium and phosphorus, and their use must be monitored closely. Despite the introduction of new medications over the past decade, such as calcium-free phosphate binders and newer vitamin D sterols, a significant proportion of patients routinely receiving dialysis have unacceptably high plasma PTH levels, marked hypercalcemia and hyperphosphatemia, and elevated $\mathrm{Ca} \times \mathrm{P}$ product levels [4-7]. In addition, it is clear that these abnormalities begin in the early stages of CKD [2].

The purpose of this review is to present recent findings linking the pathophysiology of secondary HPT with an increased risk of morbidity and mortality, to evaluate current treatment approaches with respect to the challenges inherent in the management of this disorder, and to assess future treatment options.

\section{The Pathophysiology of Secondary HPT}

A primary function of PTH is to maintain calcium levels. Very small changes in extracellular ionized calcium concentration are the primary determinants of minute-tominute fluctuations in the secretion of PTH. Mineral homeostasis is achieved by PTH through four mechanisms: (1) by modifying the release of calcium and phosphorus into the blood from the bone through a change in the dissolution of bone mineral, via bone formation and resorption [8]; (2) by decreasing the renal tubular reabsorption of phosphorus [9]; (3) by increasing the renal tubular reabsorption of calcium [10], and (4) by indirectly controlling the gastrointestinal absorption of both calcium and phosphorus through the renal synthesis of calcitriol $[10,11]$. As the kidney plays an integral role in the maintenance of normal calcium and phosphorus homeostasis, these mechanisms are all impaired during renal failure, and the resulting decrease in serum ionized calcium leads to secondary HPT. In addition, hyperphosphatemia lowers serum calcium levels through its impact on the circulating, ionized form of calcium.

Hyperphosphatemia is a key factor in the development of secondary HPT. As kidney function declines, serum phosphorus levels are maintained through a compensatory decrease in the rate of renal tubular reabsorption of phosphorus, mediated largely by an elevation in serum PTH levels [9]. Although PTH-independent mechanisms also contribute [12] when the glomerular filtration rate drops below $20-25 \mathrm{ml} / \mathrm{min}$, PTH cannot increase phosphorus excretion further and hyperphosphatemia develops $[9,13-16]$. Elevated serum phosphorus and high phosphorus intake appears to increase PTH secretion [17, 18] and proliferation of parathyroid cells [19], leading to parathyroid gland hyperplasia and further PTH secretion [20]. Furthermore, recent evidence demonstrates that hyperphosphatemia may downregulate the calcium-sensing receptor, leading to a shift to the right in the calcium-PTH curve $[17,21]$.

Abnormalities in vitamin D metabolism also contribute to the progression of secondary HPT. Hyperphosphatemia inhibits the activity of the renal tubular enzyme, 25-hydroxyvitamin $\mathrm{D}_{3}$-1 $\alpha$-hydroxylase, which converts the major circulating form of vitamin $\mathrm{D}, 25(\mathrm{OH}) \mathrm{D}_{3}$, into the highly active form, $1,25(\mathrm{OH})_{2} \mathrm{D}_{3}$ or calcitriol; this conversion is also impaired by the kidney damage itself and the uremic state. Under normal conditions, calcitriol acts directly to decrease the synthesis of PTH by binding to the vitamin D receptor (VDR) in the nucleus of the parathyroid cell. Upon binding to calcitriol, the VDR undergoes a conformational change and forms a complex with the retinoid $X$ receptor [22]. This VDR/retinoid $X$ receptor complex then binds to specific sequences in target genes and alters the rate of gene transcription [22]; one effect is to reduce transcription for the pre-pro-PTH gene, the first step in PTH synthesis [23]. Calcitriol can also inhibit PTH indirectly by increasing the intestinal absorption of calcium [24]. In renal disease, the synthesis of calcitriol is reduced and the normal endocrine feedback loop to control PTH synthesis is therefore broken. The main factors contributing to the development of secondary HPT in patients with CKD are summarized in figure 1. 
Fig. 1. Factors contributing to the development of secondary HPT in patients with CKD.

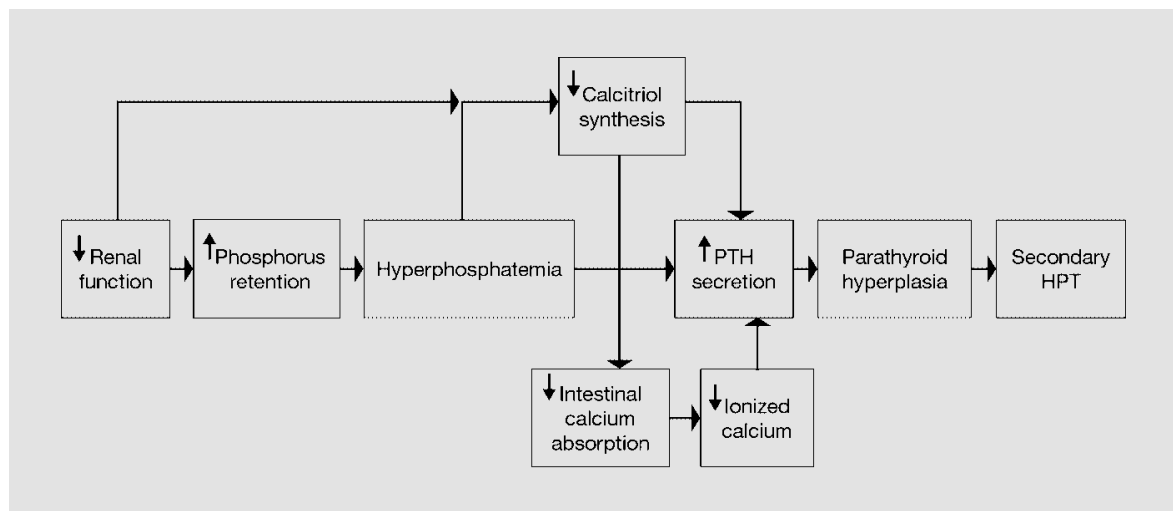

\section{Morbidity and Mortality Associated with Secondary HPT}

The list of detrimental effects associated with secondary HPT is extensive. Two major areas of concern are renal osteodystrophy, which includes osteitis fibrosa cystica and adynamic bone disease, and progressive vascular calcification [25, 26]. Vascular calcification is one mechanism by which secondary HPT is associated with an increased risk of death due to cardiovascular disease in patients receiving hemodialysis $[5,7,27]$. Cardiovascular disease accounts for nearly half of all deaths in patients with stage 5 CKD (end-stage renal disease) [28, 29].

Renal osteodystrophy is a common and potentially debilitating complication of secondary HPT. In the presence of elevated PTH levels, the turnover of bone is excessively rapid, resulting in structurally inferior woven bone that replaces the normal lamellar bone [30]. Both osteoblastic bone formation and osteoclastic bone resorption are accelerated, resulting in enhanced peritrabecular fibrosis, or osteitis fibrosa cystica [30]. In contrast, adynamic bone disease is usually observed in the presence of PTH levels that are relatively low for patients with CKD [31-34]. Adynamic bone disease is characterized by low rates of bone formation, normal or reduced amounts of osteoid, the absence of peritrabecular fibrosis, and decreased numbers of both osteoblasts and osteoclasts [34, 35]. Patients with this condition are often asymptomatic, but are at increased risk for fractures and hypercalcemia because the adynamic bone is unable to buffer an acute calcium load [36, 37].

The prevalence of different forms of renal osteodystrophy appears to be changing - adynamic bone disease is increasing, while osteitis fibrosa cystica is decreasing [35, 38]. These shifts in prevalence may reflect differences in the dialysis population and changes and advances in treatment regimens that have occurred in the past decade. Clinically, the use of both calcium-based phosphate binders and active vitamin D sterols has been associated with adynamic bone disease $[35,36,39,40]$. For example, the intake of large doses of calcium-based phosphate binders increases the total calcium burden and the potential for raising serum calcium levels, thus exacerbating the hypercalcemia of adynamic bone disease. In addition, vitamin D sterols may increase intestinal calcium and phosphate absorption, cause oversuppression of PTH, and directly lower bone formation by reducing the number of active osteoblasts [41] and, perhaps, by impairing normal PTH oscillation.

In addition, increased and decreased PTH levels have both been linked to the risk of fracture [37, 42, 43]. In patients with end-stage renal disease, a 'J-shaped' relationship between PTH concentration and fractures has been suggested by available data [37, 43]. Sustained high levels of PTH stimulate bone demineralization and high bone turnover, which lead to bone fragility and increased risk for fracture [42]. Also, when PTH levels are too low, the paucity of active cells in adynamic bone disease may impair the ability of bone to repair microfractures and thus predispose to fractures.

The association of soft-tissue and vascular calcification with advanced CKD was reported as early as 1855 in a case study of 5 individuals with metastatic calcification, 3 of whom suffered from renal disease [44, 45]. This is significant as the presence of vascular calcification is associated with a high risk of cardiac events among uremic patients [46]. Vascular calcification causes stiffening of the vessel wall, which has been found to predict cardiovascular mortality among stage 5 CKD patients receiving dialysis [47, 48]. Furthermore, soft-tissue calcification includes the calcification of the myocardium and cardiac valve, which also has important consequences on cardiac function [49]. 
Although cardiovascular disease is the leading cause of death in patients with stage 5 CKD $[50,51]$, the traditional 'Framingham' risk factors do not account completely for this high mortality rate [52]. In addition to the traditional vascular risk factors, there is increasing evidence that elevated serum phosphorus, serum $\mathrm{Ca} \times \mathrm{P}$ product, and/or calcium load in the form of calcium-containing phosphate binders are associated with vascular disease, including coronary artery calcification (as assessed by electron beam computed tomography) [53, 54], calcific uremic arteriolopathy (CUA; calciphylaxis) [55], carotid and aortic calcification $[47,56]$, hemodynamic abnormalities [57], and valvular disease [58].

A recent study by Chertow et al. [59] suggested that the noncalcium phosphate binder, sevelamer hydrochloride, may actually arrest coronary artery and aorta vascular calcification in stage $5 \mathrm{CKD}$ patients receiving dialysis, whereas calcium-based phosphate binders may increase calcification both in coronary arteries and the aorta. The median percentage change in calcium score, as measured by electron beam tomography, was greater with the calcium-based phosphate binder than with sevelamer hydrochloride: $25 \%$ vs. $6 \%$ for coronary arteries and $28 \%$ vs. $5 \%$ for aorta, respectively [59]. A baseline assessment of these patients determined that over $80 \%$ had significant coronary artery calcification, and that the severity of calcification correlated with a history of cardiac disease [60]. Furthermore, Blacher et al. [61] found, using a semiquantitative assessment of vascular calcium deposits by ultrasound, that the risk of cardiovascular and all-cause mortality is associated with the severity of arterial calcification. Extensive arterial calcification is also associated with increased arterial stiffness, which leads to increased pulse pressure and is, itself, an independent predictor of cardiovascular death among CKD patients receiving dialysis $[62,63]$. These results confirm the importance of mineral metabolism in relation to cardiovascular disease and vascular calcification.

Extraskeletal calcification affecting dialysis patients has previously been considered to be secondary to passive precipitation of supersaturated mineral content, as assessed by $\mathrm{Ca} \times \mathrm{P}$ product levels. However, in CUA, medial calcification has recently been shown to be accompanied by expression of the bone protein, osteopontin, and electron microscopy of CUA specimens revealed the presence of matrix vesicles identical to those observed in human bone [55]. In addition, there was increased expression of the classic bone proteins, bone sialoprotein and osteonectin, in the vessels of patients with CUA [Moe et al., unpubl. data]. A prospective analysis, evaluating infe- rior epigastric arteries obtained from stage 5 CKD patients at the time of renal transplantation, has also been performed. The degree of vascular calcification, as observed by both spiral CT and histologic staining for calcification, was proportional to the expression of the bone matrix proteins bone sialoprotein, osteopontin, alkaline phosphatase and type I collagen. Furthermore, positive immunostaining for these bone proteins was observed more frequently than overt calcification, which suggests that the deposition of these proteins precedes calcification [64]. These results confirm a cell-mediated, osteogenic process in vascular calcification in stage 5 CKD patients receiving dialysis, which is similar to findings in the vessels of nondialysis patients with both calcified atherosclerotic coronary arteries [65-69] and medial calcinosis in small distal vessels [67].

Thus, there is mounting evidence that disturbances of mineral metabolism in patients with CKD contribute to the increased risk of renal osteodystrophy, vascular calcification, and mortality observed in patients receiving dialysis. In addition, associations between these risks and duration of hemodialysis, calcium-containing phosphate binder use, and vitamin D administration have also been reported. It is not yet known, however, whether the associations between medical treatment and morbidity and mortality risk illustrate a direct effect of the treatment given, or are a result of the secondary effects of such treatment on mineral metabolism and bone cells.

\section{Management of Secondary HPT}

Various treatment strategies are currently recommended to correct mineral metabolism and bone disease in patients with CKD. These include dietary phosphate restriction, phosphate binders to reverse hyperphosphatemia, appropriate phosphate removal by dialysis, maintenance of adequate calcium levels, the administration of calcitriol or other vitamin D sterols to suppress PTH secretion, and, with severe secondary HPT, surgical parathyroidectomy (table 1).

\section{Control of Hyperphosphatemia}

As described earlier, the retention of phosphorus in patients with CKD is closely associated with the development and worsening of secondary HPT. For this reason, phosphorus control is a critical aspect of successful therapy for secondary HPT. Dietary restriction of phosphate was shown to significantly reduce serum phosphorus concentrations and PTH levels in 23 patients with advanced 
Table 1. Treatment options for correcting mineral metabolism and bone disease in CKD patients with secondary HPT

\begin{tabular}{|c|c|c|}
\hline Treatment & Indication & Adverse effects/limitations \\
\hline Dietary phosphate restriction & Hyperphosphatemia & Inadequate protein intake, poor compliance \\
\hline Phosphate binders & Hyperphosphatemia & \\
\hline Aluminum-containing & & Aluminum toxicity \\
\hline Calcium-containing & & $\begin{array}{l}\text { Soft tissue/vascular calcification, hypercalcemia, } \\
\text { oversuppression of PTH }\end{array}$ \\
\hline Magnesium-containing & & $\begin{array}{l}\text { Long-term exposure not studied, poor } \\
\text { gastrointestinal tolerance }\end{array}$ \\
\hline Aluminum/calcium-free & & Hypocalcemia \\
\hline Calcitriol/vitamin D analogs & $\begin{array}{l}\text { Suppression of PTH secretion, } \\
\text { hypocalcemia }\end{array}$ & $\begin{array}{l}\text { Oversuppression of PTH, hyperphosphatemia, } \\
\text { hypercalcemia }\end{array}$ \\
\hline Parathyroidectomy & Parathyroid gland hyperplasia & $\begin{array}{l}\text { Surgical, irreversible; possibility of } \\
\text { hypoparathyroidism }\end{array}$ \\
\hline
\end{tabular}

CKD who were given a very low protein diet, while serum calcium levels remained unchanged and nutritional status remained satisfactory [70]. Calcitriol levels also decreased slightly. However, given the risk of malnutrition associated with inadequate protein intake, along with poor patient acceptance and the high frequency of noncompliance, this management strategy is insufficient to control serum phosphorus levels in the majority of patients.

Dialysis, particularly continuous ambulatory peritoneal dialysis, can be an effective method for the removal of phosphorus [71]. However, it may also be unsuccessful as patients undergoing dialysis are recommended high protein diets, and at present, no current dialysis modality can counter the increased amount of phosphorus [24]. Therefore, phosphate binders are required in nearly all patients on dialysis to treat secondary HPT. Three general classes of phosphate binders exist: aluminum based, calcium based, and noncalcium/nonaluminum based.

The primary phosphate binder used until the mid 1980s was aluminum hydroxide. Although this binder is very efficient, aluminum-induced toxic side effects, such as osteomalacia, fractures, myopathy, microcytic anemia, and a fatal encephalopathy, are now known to be associated with its use [24, 72-79]. Consequently, aluminum hydroxide phosphate binders are now rarely prescribed, except in cases in which all other treatments to control phosphorus levels have been exhausted.

Over the past 15 years, calcium carbonate and calcium acetate have become the mainstay of therapy to control phosphorus levels. These phosphate binders have proved effective when compared with placebo [80-82], and facili- tate the prevention of secondary HPT by lowering phosphorus levels [83], and by directly suppressing PTH secretion. However, their effectiveness is limited by their propensity to be absorbed and, potentially, to be deposited in soft tissues, especially if serum phosphorus levels remain elevated [84]. In addition, the use of large quantities of calcium-based phosphate binders is correlated with increased coronary artery calcification [47, 53, 59]. Theoretically, calcium absorption with calcium acetate is less than that with calcium carbonate, on a gram-for-gram basis $[85,86]$. However, the use of calcium acetate has not been consistently associated with a reduced prevalence of hypercalcemic episodes [87]. Other calcium supplements, such as calcium ketoamino acids [88], calcium ketovaline [89], and calcium citrate, have also been used as phosphate binders. However, the use of calcium citrate should be avoided as citrate markedly increases the intestinal absorption of aluminum [90].

Treatment with calcium-based phosphate binders may need to be adjusted when used in conjunction with calcitriol or other active vitamin D sterols because of hypercalcemia. However, the poor phosphorus control that often arises following a reduction in phosphate binder dose can lead to a continued phosphate-mediated increase in PTH synthesis and parathyroid cell hyperplasia. This places an obvious and significant limitation on the successful management of secondary HPT with calcium-based phosphate binders combined with active vitamin D therapy.

Concerns about aluminum toxicity and hypercalcemia have led to the development of aluminum- and calciumfree phosphate binders. As described earlier, one such 
phosphate binder is sevelamer hydrochloride. This cationic hydrogel of cross-linked poly(allylamine hydrochloride) interacts with phosphate through anionic and hydrogen bonding and is not absorbed from the intestine [91, 92]. It has been shown to be effective in lowering PTH levels, reducing $\mathrm{Ca} \times \mathrm{P}$, and controlling serum phosphorus in patients receiving hemodialysis [91-95]. Furthermore, fewer hypercalcemic episodes are reported when sevelamer hydrochloride is administered compared with calcium-based phosphate binders [59, 92]. In a study in which sevelamer hydrochloride and calcium acetate were compared, only $5 \%$ of patients receiving sevelamer hydrochloride experienced episodes of hypercalcemia, but 23\% required supplementation with calcium carbonate because of hypocalcemia [92].

Another noncalcium-based phosphate binder available in the United States is magnesium carbonate, usually administered in combination with calcium carbonate. Dialysate magnesium concentration should be lowered in patients taking oral magnesium to prevent severe diarrhea $[24,96]$; however, in practice, such a recommendation is impractical given that most dialysis units use central delivery of dialysate. Furthermore, it should be noted that no studies have been carried out to determine the effects of long-term exposure to magnesium.

Lanthanum carbonate is a noncalcium, nonaluminum phosphate binder currently under development. Studies in animals [97] and dialysis patients demonstrated the efficacy of this phosphate binder [98], and preliminary studies in larger patient populations show promise [99, 100]. Compared with calcium carbonate, the use of lanthanum carbonate appears to result in a significantly greater reduction in $\mathrm{Ca} \times \mathrm{P}$, with fewer hypercalcemic episodes [100]. However, although bone biopsies conducted at 1 year failed to show any osteomalacia [101], concerns remain that long-term accumulation of this rare earth element may cause toxicity.

Recently, ferric compounds have also been shown to be effective as phosphate binders in a few limited studies [102-104]. Ferric citrate has been compared with calcium carbonate in order to assess their respective efficacy in controlling phosphate levels [105]. Although both treatments resulted in significant reductions in serum phosphorus, calcium carbonate was more effective; however, calcium carbonate also led to increases in serum calcium concentrations. PTH levels did not change with ferric citrate treatment, but were reduced with calcium carbonate treatment, probably as a consequence of the elevations in serum calcium.

\section{Calcitriol and Vitamin D Analogs}

Restoration of vitamin D levels in patients with secondary HPT helps to restore the PTH-calcium-vitamin D endocrine feedback loop that is critical for mineral homeostasis and normal serum calcium levels [106]. The first clinical use of vitamin D sterols for treating secondary HPT occurred in the early 1970s, after calcitriol or alfacalcidol administration had been shown to reduce PTH levels and increase serum calcium levels [107, 108].

Calcitriol can be effective for suppressing PTH overproduction and improving bone histology, but it also acts on the intestine to promote the intestinal absorption of calcium and phosphorus. Together, these actions can lead to excessive elevation of serum calcium, worsening hyperphosphatemia, and thus a rise in $\mathrm{Ca} \times \mathrm{P}$ product $[4,106$, $109,110]$. Hence, persistent hyperphosphatemia, which is a common problem in chronic hemodialysis patients, is often aggravated by calcitriol therapy $[24,109]$. The concomitant use of calcium-based phosphate binders and calcitriol is also associated with greater risks of hypercalcemia and elevated $\mathrm{Ca} \times \mathrm{P}[82,111]$, while another drawback of calcitriol treatment relates to the oversuppression of PTH and the associated risk of adynamic bone disease [112]. As a result of these adverse effects, calcitriol treatment must be monitored carefully and dose adjustments made according to fluctuations in serum calcium and phosphorus levels.

The limitations of vitamin D therapy have spurred the development of new analogs for treating secondary HPT that address the issue of hypercalcemia [106]. Compared with calcitriol, some vitamin D analogs have a relatively high affinity for the VDR at the parathyroid gland, but are less potent in enhancing the intestinal absorption of calcium and phosphorus [113]. The lowered affinity for the serum vitamin-D-binding protein possessed by certain side-chain-modified vitamin D analogs may result in faster clearance of these agents compared with natural vitamin D metabolites, possibly making them more accessible to target cells [113].

Paricalcitol (19-nor-1,25-dihydroxyvitamin $\mathrm{D}_{2}$ ) was the first of these new vitamin D sterols to be approved in the United States by the Food and Drug Administration. In experimental animals, this analog has been shown to decrease PTH levels as effectively as calcitriol, but to cause less intestinal absorption of calcium and phosphorus [114-116]. Long-term use of paricalcitol was evaluated over a 16-month period in a sample of 37 patients with moderate-to-severe secondary HPT who were undergoing hemodialysis [114]. Mean PTH level was reduced significantly from baseline ( $901 \pm 58$ to $165 \pm 24 \mathrm{pg} / \mathrm{ml})$, and a 
dose conversion ratio of calcitriol to paricalcitol of $1: 3$ resulted in fewer episodes of hypercalcemia than a 1:4 ratio. This may be explained by the 1:4 ratio resulting in an excessively rapid decline in PTH levels, which predisposed patients to hypercalcemia.

Although studies that compared paricalcitol and calcitriol directly were completed, the results were inconclusive and have not been published. However, a secondary analysis of a randomized trial in which calcitriol was compared with paricalcitol found that among patients receiving paricalcitol, there was less sustained hypercalcemia and more rapid and sustained suppression of PTH [117]. A single-site subanalysis of 38 patients from this study demonstrated more rapid reductions in PTH levels, and a lower incidence of hyperphosphatemia (phosphorus levels $>8 \mathrm{mg} / \mathrm{dl}$ ) in patients given intravenous paricalcitol than in those who received intravenous calcitriol over a 12- to 32-week treatment period [118].

Doxercalciferol ( $1 \alpha$-hydroxyvitamin $\left.\mathrm{D}_{2}\right)$ - a second vitamin $\mathrm{D}$ analog available in the United States - is a prodrug that, like its vitamin $\mathrm{D}_{3}$ counterpart alfacalcidol, must be activated in vivo [119]. In a study of patients with $\mathrm{CKD}$, doxercalciferol treatment resulted in a significant reduction of PTH in 21 of 24 patients with moderate-tosevere secondary HPT [120]. However, the mean serum calcium level rose from 8.8 to $9.5 \mathrm{mg} / \mathrm{dl}$, and over $40 \%$ of patients experienced at least one episode of elevated calcium, while $75 \%$ experienced at least one episode of elevated phosphorus during the 12-week study period.

A direct comparison study of the oral and intravenous formulations of doxercalciferol indicates that the oral formulation may lead to a higher incidence of hypercalcemia and greater increases in serum phosphorus than the intravenous formulation [121]. Hence, the intravenous route of administration for doxercalciferol treatment may be preferred in patients prone to hypercalcemia and hyperphosphatemia [121]. As with calcitriol, doxercalciferol leads to an interaction with calcium-containing phosphate binders and excessively rapid reduction or oversuppression of PTH could potentially lead to hypercalcemia and adynamic bone disease; thus, careful monitoring of treatment remains essential.

Additional vitamin D analogs and phosphate binders are currently in use or under development outside of the United States. Maxacalcitol (22-oxacalcitriol), a vitamin $\mathrm{D}$ analog, has been approved for intravenous use in Japan, but is not yet available in the United States. In some studies, this analog has been shown to have low calcemic and phosphatemic effects in experimental animals [122] and it has been shown to reverse abnormal bone for- mation in uremic dogs [123]. It is worth noting that none of the vitamin D sterols described above are currently available in Europe.

\section{Parathyroidectomy}

Despite advances in the treatment of secondary HPT, a significant number of patients remain refractory to therapy. In these patients, hyperphosphatemia and/or hypercalcemia lead to an elevated $\mathrm{Ca} \times \mathrm{P}$ product level in association with advanced hyperplasia of the parathyroid glands, rendering the suppression of PTH secretion impossible. When this occurs, surgical parathyroidectomy currently offers the only solution that corrects the detrimental effects of secondary HPT.

Although a single-center study by Decker et al. [124] concluded that the proportion of patients requiring parathyroidectomy to control secondary HPT has remained constant over the past two decades, an analysis of the United States Renal Data System database found that the percentage of dialysis patients undergoing subtotal or total parathyroidectomy declined significantly from 1988 to 1998 [125]. This may be explained by the introduction of less toxic phosphate-binding medications, such as calcium acetate, and the improvement in dialytic phosphate removal during this period. The use of calcitriol to reduce PTH levels in both dialysis and predialysis patients may also have reduced the need for parathyroidectomy.

New treatments for secondary HPT, such as sevelamer hydrochloride and paricalcitol, have been introduced since 1999 and may continue to improve the management of the disorder. However, there is also growing awareness among physicians of the risks of hypercalcemia and hyperphosphatemia associated with both secondary HPT and standard therapies; thus, parathyroidectomy may be recommended more often when these mineral imbalances cannot be brought under control. In addition, patients with renal disease now live longer, owing to improvements in dialysis therapy, thus prolonging the uremic state. This may mean that a greater number of patients progress to the stage of disease where parathyroidectomy is required. Future studies will be needed to determine how these recent developments affect the rates of parathyroidectomy.

\section{Future Treatment Options for Secondary HPT}

Efforts to identify more effective treatments for renal osteodystrophy of secondary HPT continue. Daytime and nocturnal dialysis regimens have been reported to lower 
serum levels of phosphorus very efficiently and reduce or eliminate the need for phosphate binders [126-128]. However, in some of these studies, there was an increase in PTH, perhaps related to hypocalcemia. Further studies are needed to define optimal renal replacement therapies for managing renal osteodystrophy.

Several new treatments are currently under development. New phosphate binders are actively being developed, which serves as a reminder that phosphate control is problematic in many patients. Another class of agents currently in development is calcimimetics, which act as allosteric modulators of the calcium-sensing receptors (CaRs) of the parathyroid gland, thereby directly targeting the molecular mechanism by which calcium modulates PTH secretion [129]. These compounds suppress PTH secretion by increasing the sensitivity of CaRs. In contrast to vitamin D sterols, which have a slow onset of action on PTH synthesis and an effect that lasts many hours or days $[130,131]$, agents that act on the CaRs reduce PTH secretion rapidly, sometimes within minutes [129].

By directly activating the CaRs, a reduction in PTH release occurs without a concomitant increase in extracellular calcium. Currently, the only calcimimetic agent in clinical development is cinacalcet $\mathrm{HCl}$, formerly known as AMG073. Preclinical studies in rats with renal failure have demonstrated that cinacalcet $\mathrm{HCl}$ may prevent parathyroid hyperplasia by suppressing parathyroid cell proliferation [132]. Initial studies in dialysis patients have demonstrated that cinacalcet $\mathrm{HCl}$ effectively lowers $\mathrm{PTH}$ and $\mathrm{Ca} \times \mathrm{P}$ levels in CKD patients with secondary HPT [133, 134]. In one study, mean PTH levels decreased by $33 \%$ in patients receiving cinacalcet $\mathrm{HCl}$, compared with an increase of $3 \%$ in placebo patients. In addition, the $\mathrm{Ca} \times \mathrm{P}$ levels found in patients receiving cinacalcet $\mathrm{HCl}$ decreased by $8 \%$ compared with an increase of $11 \%$ in patients receiving placebo [134]. The ability of calcimimetic agents to reduce PTH levels while also lowering $\mathrm{Ca} \times \mathrm{P}$ suggests that these agents may prove more physiologic and less toxic in the management of secondary HPT. Whether these agents will be used as single agents or together with vitamin D to suppress PTH remains to be determined.

\section{Conclusion}

Dramatic advances in our understanding of the pathogenesis, pathophysiology and sequelae of secondary HPT have been made in the past decade. This significant progress should allow improvements in the management of patients with secondary HPT through the achievement of the target levels of serum phosphorus, serum calcium, $\mathrm{Ca} \times \mathrm{P}$ product, and serum $\mathrm{PTH}$, which are soon to be published in the NKF-K/DOQI Bone Metabolism and Disease Guidelines.

Currently, medical management of secondary HPT and hyperphosphatemia continues to be far from optimal, with approximately $60 \%$ of patients not achieving adequate control of $\mathrm{PTH}$, phosphorus, and $\mathrm{Ca} \times \mathrm{P}$ levels $[6$, 49]. Hopefully, further understanding of the extraskeletal effects of abnormal mineral metabolism and the development and approval of novel therapeutic agents will notably enhance our ability to achieve the NKF-K/DOQI targets in a greater number of patients.

\section{Acknowledgments}

The authors thank Lane Whitcomb (Medical Affairs Writing Department, Amgen Inc.) for his assistance in writing the manuscript.

\section{References}

1 Slatopolsky E, Delmez J: Pathogenesis of secondary hyperparathyroidism. Am J Kidney Dis 1994;23:229-236.

2 Rix M, Andreassen H, Eskildsen P, Langdahl $\mathrm{B}$, Olgaard K: Bone mineral density and biochemical markers of bone turnover in patients with predialysis chronic renal failure. Kidney Int 1999;56:1084-1093.

3 National Kidney Foundation: K/DOQI clinical practice guidelines: Bone metabolism and disease in chronic kidney disease. Am J Kidney Dis, in press.
4 Johnson CA, McCarthy J, Bailie GR, Deane J, Smith S: Analysis of renal bone disease treatment in dialysis patients. Am J Kidney Dis 2002;39:1270-1277.

5 Block GA, Hulbert-Shearon TE, Levin NW, Port FK: Association of serum phosphorus and calcium $\times$ phosphate product with mortality risk in chronic hemodialysis patients: A national study. Am J Kidney Dis 1998;31:607-617.

6 Block GA, Port FK: Re-evaluation of risks associated with hyperphosphatemia and hyperparathyroidism in dialysis patients: Recommendations for a change in management. Am J Kidney Dis 2000;35:1226-1237.
7 Ganesh SK, Stack AG, Levin NW, HulbertShearon T, Port FK: Association of elevated serum $\mathrm{PO}_{4}, \mathrm{Ca} \times \mathrm{PO}_{4}$ product, and parathyroid hormone with cardiac mortality risk in chronic hemodialysis patients. J Am Soc Nephrol 2001;12:2131-2138.

8 Martin TJ: Drug and hormone effects on calcium release from bone. Pharmacol Ther 1983; 21:209-228.

9 Slatopolsky E, Bricker NS: The role of phosphorus restriction in the prevention of secondary hyperparathyroidism in chronic renal disease. Kidney Int 1973;4:141-145. 
10 Brown EM: Extracellular $\mathrm{Ca}^{2+}$ sensing, regulation of parathyroid cell function, and role of $\mathrm{Ca}^{2+}$ and other ions as extracellular (first) messengers. Physiol Rev 1991;71:371-411.

11 Nemeth EF: Pharmacological regulation of parathyroid hormone secretion. Curr Pharm Des 2002;8:2077-2087.

12 Swenson RS, Weisinger JR, Ruggeri JL, Reaven GM: Evidence that parathyroid hormone is not required for phosphate homeostasis in renal failure. Metabolism 1975;24:199-204.

13 Better OS, Kleeman CR, Gonick HC, Varrady PD, Maxwell MH: Renal handling of calcium, magnesium and inorganic phosphate in chronic renal failure. Isr J Med Sci 1967;3:60_ 79 .

14 Slatopolsky E, Robson AM, Elkan I, Bricker NS: Control of phosphate excretion in uremic man. J Clin Invest 1968;47:1865-1874.

15 Hosking DJ, Chamberlain MJ: Calcium balance in chronic renal failure. A study using in vivo neutron activation analysis. Q $\mathrm{J} \mathrm{Med}$ 1973;42:467-479.

16 Brenner B: Disturbances of Renal Function. New York, McGraw-Hill, 1994.

17 Almaden Y, Hernandez A, Torregrosa V, Canalejo A, Sabate L, Fernandez Cruz L, Campistol JM, Torres A, Rodriguez M: High phosphate level directly stimulates parathyroid hormone secretion and synthesis by human parathyroid tissue in vitro. J Am Soc Nephrol 1998; 9:1845-1852.

18 Slatopolsky E, Finch J, Denda M, Ritter C, Zhong M, Dusso A, MacDonald PN, Brown AJ: Phosphorus restriction prevents parathyroid gland growth. High phosphorus directly stimulates PTH secretion in vitro. J Clin Invest 1996;97:2534-2540.

19 Roussanne MC, Lieberherr M, Souberbielle JC, Sarfati E, Drueke T, Bourdeau A: Human parathyroid cell proliferation in response to calcium, NPS R-467, calcitriol and phosphate. Eur J Clin Invest 2001;31:610-616.

20 Naveh-Many T, Rahamimov R, Livni N, Silver $\mathrm{J}$ : Parathyroid cell proliferation in normal and chronic renal failure rats. The effects of calcium, phosphate, and vitamin D. J Clin Invest 1995;96:1786-1793.

21 Brown AJ, Ritter CS, Finch JL, Slatopolsky EA: Decreased calcium-sensing receptor expression in hyperplastic parathyroid glands of uremic rats: Role of dietary phosphate. Kidney Int 1999;55:1284-1292.

22 Kliewer SA, Umesono K, Mangelsdorf DJ, Evans RM: Retinoid X receptor interacts with nuclear receptors in retinoic acid, thyroid hormone and vitamin $\mathrm{D}_{3}$ signalling. Nature 1992; 355:446-449.

23 Silver J, Naveh-Many T, Mayer H, Schmelzer HJ, Popovtzer MM: Regulation by vitamin D metabolites of parathyroid hormone gene transcription in vivo in the rat. J Clin Invest 1986; 78:1296-1301.

24 Delmez JA, Slatopolsky E: Hyperphosphatemia: Its consequences and treatment in patients with chronic renal disease. Am J Kidney Dis 1992;19:303-317.
25 Fukagawa M, Kazama JJ, Kurokawa K: Renal osteodystrophy and secondary hyperparathyroidism. Nephrol Dial Transplant 2002;17 (suppl 10):2-5.

26 Moe SM: Current issues in the management of secondary hyperparathyroidism and bone disease. Perit Dial Int 2001;21:S241-S246.

27 Chertow G, Lowrie E, Lew N: Mineral metabolism and mortality on dialysis. J Am Soc Nephrol 2000;11:A2958.

28 Bloembergen WE: Cardiac disease in chronic uremia: Epidemiology. Adv Ren Replace Ther 1997;4:185-193.

29 United States Renal Data System. USRDS 1999 Annual Report. Bethesda, National Institutes of Health, National Institute of Diabetes and Digestive and Kidney Diseases, 1999.

30 Hruska K: Pathophysiology of renal osteodystrophy. Pediatr Nephrol 2000;14:636-640.

31 Mathias R, Salusky I, Harman W, Paredes A, Emans J, Segre G, Goodman W: Renal bone disease in pediatric and young adult patients on hemodialysis in a children's hospital. J Am Soc Nephrol 1993;3:1938-1946.

32 Hercz G, Pei Y, Grennwood C, Manuel A, Saiphoo C, Goodman W, Segre GV, Fenton S, Sherrard DJ: Aplastic osteodystrophy without aluminum: The role of 'suppressed' parathyroid function. Kidney Int 1993;44:860-866.

33 Salusky IB, Ramirez JA, Oppenheim W, Gales B, Segre GV, Goodman WG: Biochemical markers of renal osteodystrophy in pediatric patients undergoing CAPD/CCPD. Kidney Int 1994;45:253-258.

34 Goodman WG, Veldhuis JD, Belin TR, Juppner H, Salusky IB: Suppressive effect of calcium on parathyroid hormone release in adynamic renal osteodystrophy and secondary hyperparathyroidism. Kid Int 1997;51:15901595.

35 Sherrard DJ, Hercz G, Pei Y, Maloney NA, Greenwood C, Manue 1A, Saiphoo C, Fenton SS, Segre GV: The spectrum of bone disease in end-stage renal failure - An evolving disorder. Kidney Int 1993;43:436-442.

36 Kurz P, Monier-Faugere MC, Bognar B, Werner E, Roth P, Vlachojannis J, Malluche $\mathrm{HH}$ : Evidence for abnormal calcium homeostasis in patients with adynamic bone disease. Kidney Int 1994;46:855-861.

37 Coco M, Rush H: Increased incidence of hip fractures in dialysis patients with low serum parathyroid hormone. Am J Kidney Dis 2000; 36:1115-1121.

38 Gal-Moscovici A, Popovtzer MM: Parathyroid hormone-independent osteoclastic resorptive bone disease: A new variant of adynamic bone disease in haemodialysis patients. Nephrol Dial Transplant 2002;17:620-624.

39 Llach F, Felsenfeld AJ, Coleman MD, Keveney JJ, Pederson JA, Medlock TR: The natural course of dialysis osteomalacia. Kidney Int 1986;18:S74-S79.

40 Couttenye MM, D'Haese PC, Deng JT, Van Hoof VO, Verpooten GA, De Broe ME: High prevalence of adynamic bone disease diagnosed by biochemical markers in a wide sample of the European CAPD population. Nephrol Dial Transplant 1997;12:2144-2150.
41 Andress DL, Norris KC, Coburn JW, Slatopolsky EA, Sherrard DJ: Intravenous calcitriol in the treatment of refractory osteitis fibrosa of chronic renal failure. N Engl J Med 1989;321: 274-279.

42 Martin KJ, Gonzalez EA: Strategies to minimize bone disease in renal failure. Am J Kidney Dis 2001;38:1430-1436.

43 Atsumi K, Kushida K, Yamazaki K, Shimizu $\mathrm{S}$, Ohmura A, Inoue T: Risk factors for vertebral fractures in renal osteodystrophy. Am J Kidney Dis 1999;33:287-293.

44 Virchow R: Kall metastasen. Virchows Arch Pathol Anat 1855;8:103-113.

45 Qunibi WY, Nolan CA, Ayus JC: Cardiovascular calcification in patients with end-stage renal disease: A century-old phenomenon. Kidney Int Suppl 2002;62:73-80.

46 Salgueira M, Del Toro N, Moreno-Alba R, Jimenez E, Areste N, Palma A: Vascular calcification in the uremic patient: A cardiovascular risk? Kidney Int Suppl 2003;85:119-121.

47 Guerin AP, London GM, Marchais SJ, Metivier F: Arterial stiffening and vascular calcifications in end-stage renal disease. Nephrol Dial Transplant 2000;15:1014-1021.

48 Blacher J, Demuth K, Guerin AP, Safar ME, Moatti N, London GM: Influence of biochemical alterations on arterial stiffness in patients with end-stage renal disease. Arterioscler Thromb Vasc Biol 1998;18:535-541.

49 Raggi P, Boulay A, Chasan-Taber S, Amin N, Dillon M, Burke SK, Chertow GM: Cardiac calcification in adult hemodialysis patients. A link between end-stage renal disease and cardiovascular disease? J Am Coll Cardiol 2002; 39:695-701.

50 Levin A, Djurdjev O, Barrett B, Burgess E, Carlisle E, Ethier J, Jindal K, Mendelssohn D, Tobe S, Singer J, Thompson C: Cardiovascular disease in patients with chronic kidney disease: Getting to the heart of the matter. Am J Kidney Dis 2001;38:1398-1407.

51 Collins AJ: Cardiovascular mortality in endstage renal disease. Am J Med Sci 2003;325: 163-167.

52 Cheung AK, Sarnak MJ, Yan G, Dwyer JT, Heyka RJ, Rocco MV, Teehan BP, Levey AS: Atherosclerotic cardiovascular disease risks in chronic hemodialysis patients. Kidney Int 2000;58:353-362.

53 Goodman WG, Goldin J, Kuizon BD, Yoon C, Gales B, Sider D, Wang Y, Chung J, Emerick A, Greaser L, Elashoff RM, Salusky IB: Coronary-artery calcification in young adults with end-stage renal disease who are undergoing dialysis. N Engl J Med 2000;342:1478-1483.

54 Raggi P: Imaging of cardiovascular calcifications with electron beam tomography in hemodialysis patients. Am J Kidney Dis 2001;37: S62-S65.

55 Ahmed S, O'Neill KD, Hood AF, Evan AP, Moe SM: Calciphylaxis is associated with hyperphosphatemia and increased osteopontin expression by vascular smooth muscle cells. Am J Kidney Dis 2001;37:1267-1276. 
56 Kimura K, Saika Y, Otani H, Fujii R, Mune M, Yukawa S: Factors associated with calcification of the abdominal aorta in hemodialysis patients. Kidney Int Suppl 1999;71:S238S241.

57 Marchais SJ, Metivier F, Guerin AP, London GM: Association of hyperphosphataemia with haemodynamic disturbances in end-stage renal disease. Nephrol Dial Transplant 1999;14: 2178-2183.

58 Rubel JR, Milford EL: The relationship between serum calcium and phosphate levels and cardiac valvular procedures in the hemodialysis population. Am J Kidney Dis 2003;41:411421.

59 Chertow GM, Burke SK, Raggi P: Sevelamer attenuates the progression of coronary and aortic calcification in hemodialysis patients. Kidney Int 2002;62:245-252.

60 Raggi P, Rienmuller R, Chertow G: Cardiac calcification is prevalent and severe in ESRD patients as measured by electron beam CT scanning. J Am Soc Nephrol 2000;A0405:75A.

61 Blacher J, Guerin AP, Pannier B, Marchais SJ, London GM: Arterial calcifications, arterial stiffness, and cardiovascular risk in end-stage renal disease. Hypertension 2001;38:938-942.

62 Blacher J, Guerin AP, Pannier B, Marchais SJ Safar ME, London GM: Impact of aortic stiffness on survival in end-stage renal disease. Circulation 1999;99:2434-2439.

63 London GM, Marchais SJ, Guerin AP, Metivier $\mathrm{F}$, Adda $\mathrm{H}$ : Arterial structure and function in end-stage renal disease. Nephrol Dial Transplant 2002;17:1713-1724.

64 Moe SM, O’Neill KD, Duan D, Ahmed S, Chen NX, Leapman SB, Fineberg N, Kopecky $\mathrm{K}$ : Medial artery calcification in ESRD patients is associated with deposition of bone matrix proteins. Kidney Int 2002;61:638-647.

65 Bostrom K, Watson KE, Horn S, Wortham C, Herman IM, Demer LL: Bone morphogenetic protein expression in human atherosclerotic lesions. J Clin Invest 1993;91:1800-1809.

66 Fitzpatrick LA, Severson A, Edwards WD, Ingram RT: Diffuse calcification in human coronary arteries. Association of osteopontin with atherosclerosis. J Clin Invest 1994;94:15971604.

67 Shanahan CM, Cary NR, Metcalfe JC, Weissberg PL: High expression of genes for calcification-regulating proteins in human atherosclerotic plaques. J Clin Invest 1994;93:23932402.

68 Nakaoka T, Gonda K, Ogita T, Otawara-Hamamoto Y, Okabe F, Kira Y, Harii K, Miyazono K, Takuwa Y, Fujita T: Inhibition of rat vascular smooth muscle proliferation in vitro and in vivo by bone morphogenetic protein-2. J Clin Invest 1997;100:2824-2832.

69 Proudfoot D, Skepper JN, Shanahan CM, Weissberg PL: Calcification of human vascular cells in vitro is correlated with high levels of matrix Gla protein and low levels of osteopontin expression. Arterioscler Thromb Vasc Bio 1998;18:379-388.
70 Aparicio M, Combe C, Lafage MH, de Precigout V, Potaux L, Bouchet JL: In advanced renal failure, dietary phosphorus restriction reverses hyperparathyroidism independent of changes in the levels of calcitriol. Nephron 1993;63:122-123.

71 Cannata-Andia JB, Rodriguez-Garcia M: Hyperphosphataemia as a cardiovascular risk factor - How to manage the problem. Nephrol Dial Transplant 2002;17 Suppl 11:16-19.

72 Kates D: Control of hyperphosphatemia in renal failure: Role of aluminum. Semin Dial 1996;9:310-315.

73 Parkinson IS, Ward MK, Feest TG, Fawcett RW, Kerr DN: Fracturing dialysis osteodystrophy and dialysis encephalopathy. An epidemiological survey. Lancet 1979;ii:406-409.

74 Alfrey AC, Mishell JM, Burks J, Contiguglia SR, Rudolph H, Lewin E, Holmes JH: Syndrome of dyspraxia and multifocal seizures associated with chronic hemodialysis. Trans Am Soc Artif Intern Organs 1972;18:257-261, 266-267.

75 Nebeker HG, Coburn JW: Aluminum and renal osteodystrophy. Annu Rev Med 1986;37: 79-95.

76 Alfrey A: Aluminum intoxication. N Engl J Med 1984;310:1113-1115.

77 Alfrey AC, LeGendre GR, Kaehny WD: The dialysis encephalopathy syndrome. Possible aluminum intoxication. N Engl J Med 1976; 294:184-188.

78 Platts MM, Anastassiades E: Dialysis encephalopathy: Precipitating factors and improvement in prognosis. Clin Nephrol 1981;15:223228.

79 Platts MM, Goode GC, Hislop JS: Composition of the domestic water supply and the incidence of fractures and encephalopathy in patients on home dialysis. Br Med J 1977;2:657660

80 Slatopolsky E, Weerts C, Stokes T, Windus D, Delmez J: Alternative phosphate binders in dialysis patients: Calcium carbonate. Semin Nephrol 1986;6:35-41.

81 Slatopolsky E, Weerts C, Lopez-Hilker S, Norwood K, Zink M, Windus D, Delmez J: Calcium carbonate as a phosphate binder in patients with chronic renal failure undergoing dialysis. N Engl J Med 1986;315:157-161.

82 Emmett M, Sirmon MD, Kirkpatrick WG, Nolan CR, Schmitt GW, Cleveland MB: Calcium acetate control of serum phosphorus in hemodialysis patients. Am J Kidney Dis 1991;17: 544-550.

83 Delmez JA, Tindira CA, Windus DW, Norwood KY, Giles KS, Nighswander TL, Slatopolsky E: Calcium acetate as a phosphorus binder in hemodialysis patients. J Am Soc Nephrol 1992;3:96-102.

84 Locatelli F, Cannata-Andia JB, Drüeke TB, Horl WH, Fouque D, Heimburger O, Ritz E: Management of disturbances of calcium and phosphate metabolism in chronic renal insufficiency, with emphasis on the control of hyperphosphataemia. Nephrol Dial Transplant 2002;17:723-731.
85 Sheikh MS, Maguire JA, Emmett M, Santa Ana CA, Nicar MJ, Schiller LR, Fordtran JS: Reduction of dietary phosphorus absorption by phosphorus binders. A theoretical, in vitro, and in vivo study. J Clin Invest 1989;83:66-73.

86 Mai ML, Emmett M, Sheikh MS, Santa Ana CA, Schiller L, Fordtran JS: Calcium acetate, an effective phosphorus binder in patients with renal failure. Kidney Int 1989;36:690-695.

87 d'Almeida Filho EJ, da Cruz EA, Hoette M, Ruzany F, Keen LN, Lugon JR: Calcium acetate versus calcium carbonate in the control of hyperphosphatemia in hemodialysis patients. Sao Paulo Med J 2000;118:179-184.

88 Macia M, Coronel F, Navarro JF, Gallego E, Herrero JA, Mendez ML, Chahin J, Garcia J Calcium salts of keto-amino acids, a phosphate binder alternative for patients on CAPD. Clin Nephrol 1997;48:181-184.

89 Schaefer K, von Herrath D, Erley CM, Asmus $\mathrm{G}$ : Calcium ketovaline as new therapy for uremic hyperphosphatemia. Miner Electrolyte Metab 1990;16:362-364.

90 Nolan CR, Califano JR, Butzin CA: Influence of calcium acetate or calcium citrate on intestinal aluminum absorption. Kidney Int 1990;38: 937-941.

91 Chertow GM, Burke SK, Lazarus JM, Stenzel KH, Wombolt D, Goldberg D, Bonventre JV, Slatopolsky E: Poly[allylamine hydrochloride] (RenaGel): A noncalcemic phosphate binder for the treatment of hyperphosphatemia in chronic renal failure. Am J Kidney Dis 1997; 29:66-71.

92 Bleyer AJ, Burke SK, Dillon M, Garrett B, Kant KS, Lynch D, Rahman SN, Schoenfeld P, Teitelbaum I, Zeig S, Slatopolsky E: A comparison of the calcium-free phosphate binder sevelamer hydrochloride with calcium acetate in the treatment of hyperphosphatemia in hemodialysis patients. Am J Kidney Dis 1999;33: 694-701.

93 Slatopolsky EA, Burke SK, Dillon MA: RenaGel, a nonabsorbed calcium- and aluminumfree phosphate binder, lowers serum phosphorus and parathyroid hormone. The RenaGel Study Group. Kidney Int 1999;55:299-307.

94 Chertow GM, Dillon M, Burke SK, Steg M, Bleyer AJ, Garrett BN, Domoto DT, Wilkes BM, Wombolt DG, Slatopolsky E: A randomized trial of sevelamer hydrochloride (RenaGel) with and without supplemental calcium. Strategies for the control of hyperphosphatemia and hyperparathyroidism in hemodialysis patients. Clin Nephrol 1999;51:18-26.

95 Goldberg DI, Dillon MA, Slatopolsky EA, Garrett B, Gray JR, Marbury T, Weinberg M, Wombolt D, Burke SK: Effect of RenaGel, a non-absorbed, calcium- and aluminium-free phosphate binder, on serum phosphorus, calcium, and intact parathyroid hormone in endstage renal disease patients. Nephrol Dial Transplant 1998;13:2303-2310.

96 Delmez JA, Kelber J, Norword KY, Giles KS, Slatopolsky E: Magnesium carbonate as a phosphorus binder: A prospective, controlled, crossover study. Kidney Int 1996;49:163-167. 
97 Graff L, Burnel D: A possible non-aluminum oral phosphate binder? A comparative study on dietary phosphorus absorption. Res Commun Mol Pathol Pharmacol 1995;89:373388.

98 Dewberry K, Fox J, Stewart J, Murray J, Hutchison AJ: Lanthanum carbonate: A novel non-calcium-containing phosphate binder. J Am Soc Nephrol 1997;8:A2610.

99 Joy M, Finn W: Fosrenol ${ }^{\mathrm{TM}}$, a novel non-calcium, non-aluminum phosphate binder, has a good safety and efficacy profile in the longterm treatment of hyperphosphatemia in hemodialysis patients. J Am Soc Nephrol 2002; 13:386A.

100 Hutchison A: The novel non-aluminum, noncalcium phosphate binder, Fosrenol ${ }^{\mathrm{TM}}$, is an effective treatment for hyperphosphatemia and has a good safety profile. J Am Soc Nephrol 2002; 13:385A.

101 D'Haese PC, Spasovski GB, Sikole A, Hutchison A, Freemont TJ, Sulkova S, Swanepoel C, Pejanovic S, Djukanovic L, Balducci A, Coen G, Sulowicz W, Ferreira A, Torres A, Curic S, Popovic M, Dimkovic N, De Broe ME: A multicenter study on the effects of lanthanum carbonate (Fosrenol) and calcium carbonate on renal bone disease in dialysis patients. Kidney Int Suppl 2003;85:73-78.

102 Hsu CH, Patel SR, Young EW: New phosphate binding agents: Ferric compounds. J Am Soc Nephrol 1999;10:1274-1280.

103 Hergesell O, Ritz E: Stabilized polynuclear iron hydroxide is an efficient oral phosphate binder in uraemic patients. Nephrol Dial Transplant 1999;14:863-867.

104 Chang JM, Hwang SJ, Tsai JC, Chen HC, Guh JY, Lai YH: Effect of ferric polymaltose complex as a phosphate binder in haemodialysis patients. Nephrol Dial Transplant 1999; 14:1045-1047.

105 Yang WC, Yang CS, Hou CC, Wu TH, Young EW, Hsu CH: An open-label, crossover study of a new phosphate-binding agent in haemodialysis patients: Ferric citrate. Nephrol Dial Transplant 2002;17:265-270.

106 Malluche HH, Mawad H, Koszewski NJ: Update on vitamin $\mathrm{D}$ and its newer analogues: Actions and rationale for treatment in chronic renal failure. Kidney Int 2002;62: 367-374.

107 Brickman AS, Coburn JW, Norman AW: Action of 1,25-dihydroxycholecalciferol, a potent, kidney-produced metabolite of vitamin $\mathrm{D}$, in uremic man. N Engl J Med 1972;287: 891-895.

108 Chalmers TM, Hunter JO, Davie MW, Szaz KF, Pelc B, Kodicek E: 1-Alpha-hydroxycholecalciferol as a substitute for the kidney hormone 1,25-dihydroxycholecalciferol in chronic renal failure. Lancet 1973;ii:696699.

109 Quarles LD, Yohay DA, Carroll BA, Spritzer CE, Minda SA, Bartholomay D, Lobaugh BA: Prospective trial of pulse oral versus intravenous calcitriol treatment of hyperparathyroidism in ESRD. Kidney Int 1994;45:17101721.
110 Rodriguez M, Felsenfeld AJ, Williams C, Pederson JA, Llach F: The effect of long-term intravenous calcitriol administration on parathyroid function in hemodialysis patients. $\mathrm{J}$ Am Soc Nephrol 1991;2:1014-1020.

111 Sperschneider H, Gunther K, Marzoll I, Kirchner E, Stein G: Calcium carbonate $\left(\mathrm{CaCO}_{3}\right)$ : An efficient and safe phosphate binder in haemodialysis patients? A 3-year study. Nephrol Dial Transplant 1993;8:530534.

112 Goodman WG, Ramirez JA, Belin TR, Chon Y, Gales B, Segre GV, Salusky IB: Development of adynamic bone in patients with secondary hyperparathyroidism after intermittent calcitriol therapy. Kidney Int 1994;46: 1160-1166.

113 Slatopolsky E, Dusso A, Brown A: New analogs of vitamin $\mathrm{D}_{3}$. Kidney Int 1999;56:S46S51.

114 Llach F, Yudd M: Paricalcitol in dialysis patients with calcitriol-resistant secondary hyperparathyroidism. Am J Kidney Dis 2001; 38:S45-S50.

115 Martin KJ, Gonzalez EA, Gellens M, Hamm LL, Abboud H, Lindberg J: 19-Nor-1-alpha25-dihydroxyvitamin $\mathrm{D}_{2}$ (Paricalcitol) safely and effectively reduces the levels of intact parathyroid hormone in patients on hemodialysis. J Am Soc Nephrol 1998;9:1427-1432.

116 Martin KJ, Gonzalez E, Lindberg JS, Taccetta C, Amdahl M, Malhotra K, Llach F: Paricalcitol dosing according to body weight or severity of hyperparathyroidism: A doubleblind, multicenter, randomized study. Am J Kidney Dis 2001;38:S57-S63.

117 Sprague SM, Llach F, Amdahl M, Taccetta C, Batlle D: Paricalcitol versus calcitriol in the treatment of secondary hyperparathyroidism. Kidney Int 2003;63:1483-1490.

118 Sprague SM, Lerma E, McCormmick D, Abraham M, Batlle D: Suppression of parathyroid hormone secretion in hemodialysis patients: comparison of paricalcitol with calcitriol. Am J Kidney Dis 2001;38:S51-S56.

119 Brown AJ, Dusso AS, Slatopolsky E: Vitamin $\mathrm{D}$ analogues for secondary hyperparathyroidism. Nephrol Dial Transplant 2002;17(suppl 10):10-19.

120 Tan AUJ, Levine BS, Mazess RB, Kyllo DM, Bishop CW, Knutson JC, Kleinman KS, Coburn JW: Effective suppression of parathyroid hormone by 1 alpha-hydroxy-vitamin $\mathrm{D}_{2}$ in hemodialysis patients with moderate to severe secondary hyperparathyroidism. Kidney Int 1997;51:317-323.

121 Maung HM, Elangovan L, Frazao JM, Bower JD, Kelley BJ, Acchiardo SR, Rodriguez HJ, Norris KC, Sigala JF, Rutkowski M, Robertson JA, Goodman WG, Levine BS, Chesney RW, Mazess RB, Kyllo DM, Douglass LL, Bishop CW, Coburn JW: Efficacy and side effects of intermittent intravenous and oral doxercalciferol (1alpha-hydroxyvitamin $\mathrm{D}_{2}$ ) in dialysis patients with secondary hyperparathyroidism: A sequential comparison. Am J Kidney Dis 2001;37:532-543.
122 Brown AJ, Ritter CR, Finch JL, Morrissey J, Martin KJ, Murayama E, Nishii Y, Slatopolsky E: The noncalcemic analogue of vitamin D, 22-oxacalcitriol, suppresses parathyroid hormone synthesis and secretion. J Clin Invest 1989;84:728-732.

123 Monier-Faugere MC, Geng Z, Friedler RM, Qi Q, Kubodera N, Slatopolsky E, Malluche HH: 22-Oxacalcitriol suppresses secondary hyperparathyroidism without inducing low bone turnover in dogs with renal failure. Kidney Int 1999;55:821-832.

124 Decker PA, Cohen EP, Doffek KM, Ashley BA, Bienemann ME, Zhu YR, Adams ME, Wilson SD, Demeure MJ: Subtotal parathyroidectomy in renal failure: Still needed after all these years. World J Surg 2001;25:708712 .

125 Cohen EP, Moulder JE: Parathyroidectomy in chronic renal failure: Has medical care reduced the need for surgery? Nephron 2001; 89:271-273

126 Pierratos A, Ouwendyk M, Francoeur R, Vas S, Raj DS, Ecclestone AM, Langos V, Uldall R: Nocturnal hemodialysis: Three-year experience. J Am Soc Nephrol 1998;9:859-868.

127 Zehnder C, Gutzwiller JP, Renggli K: Hemodiafiltration - A new treatment option for hyperphosphatemia in hemodialysis patients. Clin Nephrol 1999;52:152-159.

128 Fajardo L, Campistrus N, Rios P, Gomez T: Evolution of serum phosphate in long intermittent hemodialysis. Kidney Int Suppl 2003; 85:66-68.

129 Nemeth EF. Calcium receptors as novel drug targets; in Bilezikian JP, Raisz LG, Rodan GA (eds): Principles in Bone Biology. San Diego, Academic Press, 1996, pp 10191035.

130 Okazaki T, Igarashi T, Kronenberg HM: 5'Flanking region of the parathyroid hormone gene mediates negative regulation by 1,25 $(\mathrm{OH})_{2}$ vitamin $\mathrm{D}_{3}$. J Biol Chem 1988;263: 2203-2208.

131 Okazaki T, Zajac JD, Igarashi T, Ogata E, Kronenberg HM: Negative regulatory elements in the human parathyroid hormone gene. J Biol Chem 1991;266:21903-21910.

132 Wada M, Nagano N, Furuya Y, Chin J, Nemeth EF, Fox J: Calcimimetic NPS R-568 prevents parathyroid hyperplasia in rats with severe secondary hyperparathyroidism. Kidney Int 2000;57:50-58.

133 Lindberg JS, Moe SM, Goodman WG, Coburn JW, Sprague SM, Liu W, Blaisdell PW, Brenner RM, Turner SA, Martin KJ: The calcimimetic AMG 073 reduces parathyroid hormone and calcium $\times$ phosphorus in secondary hyperparathyroidism. Kidney Int 2003;63:248-254.

134 Quarles LD, Sherrard DJ, Adler S, Rosansky SJ, McCary LC, Liu W, Turner SA, Bushinsky DA: The calcimimetic AMG 073 as a potential treatment for secondary hyperparathyroidism of end-stage renal disease. J Am Soc Nephrol 2003;14:575-583. 